Historic, Archive Document

Do not assume content reflects current scientific knowledge, policies, or practices. 



\section{CHOICE "GLADS"}

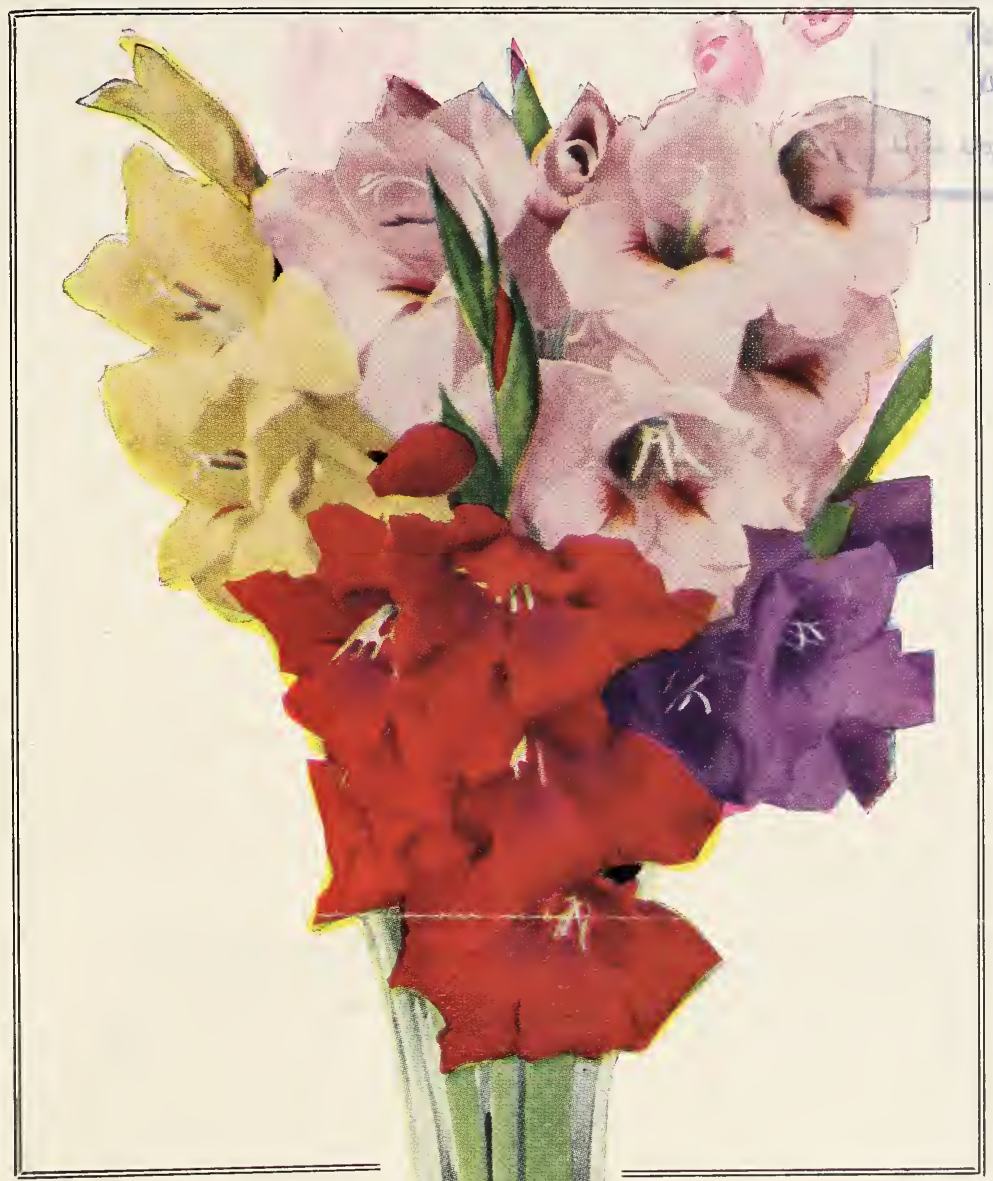

Easy to

Grow

Profuse

Bloomers
Splendid for

Bouquets

and Table

Decorations

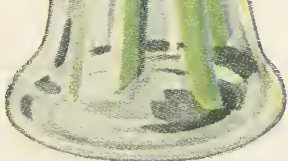

\section{AUGUSTINE \& CO., Inc.}

Nurserymen and Landscape Gardeners 



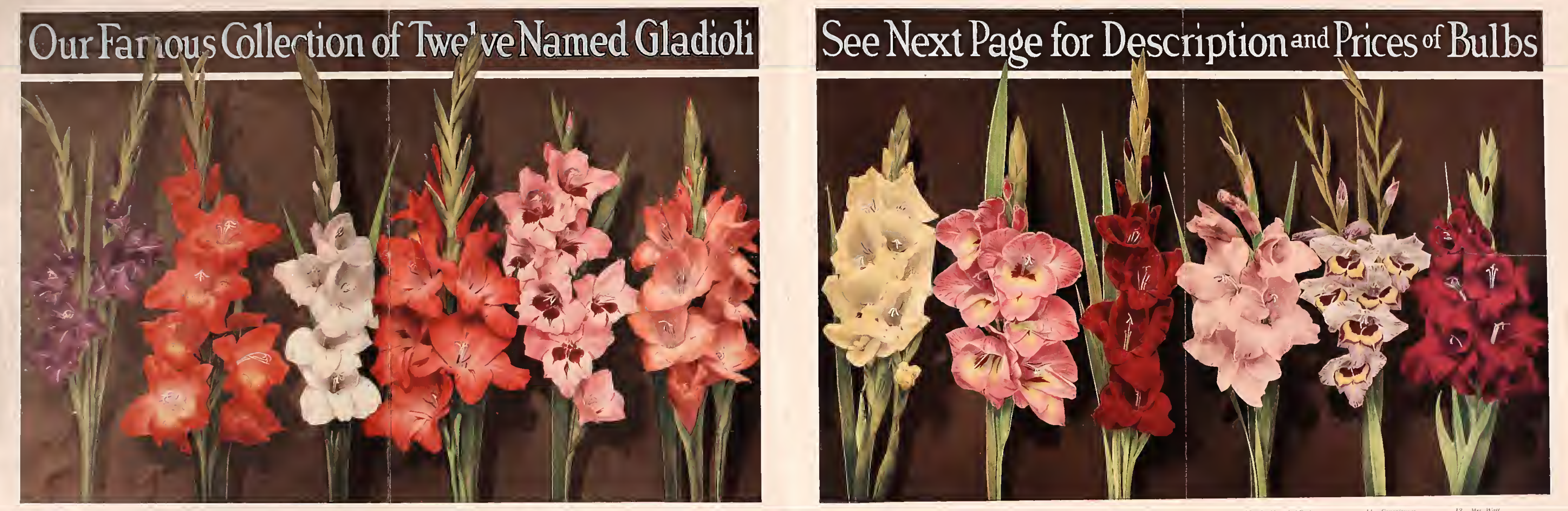





\section{Our Superb $\$ 2.50$ Collection of Gladioli}

Our color plate does not begin to do justice to these twelve beautiful 12 Named Varieties

their beautiful shades and colors. Gladioli. They should be seen growing to appreciate and order a supply of bulbs of these choice Gladioli.

See color plate on other side of this page for color of cach kind

No. 1. Baron Hulot Acknowledged to be the best blue Gladiolus, It grows a splendid, tall, the spike. The color is a rich, deep indigo blue, making it slrikingly beauliful in combination with other No. 2. Gretchen Zang A decidedly showy variety, the color being a eleat rieh orange-red
suffused wish violet shadings. The or individual, with golden yellow markings on the lower petals faintly
are of large size and stand out boldiy. No.' 3. Peace A very strong healthy grower and a free bloomer. The flowers are large, pure alraclive. The fowers are correctly placed on a heasy siraight spike, and it is one of the best of the white

No. 4. Mrs. Francis King One of the most popular variesies in cultivation The spike fowers of a rich fatme-red or pink with srawall cammine spots on the lower petals and a darker lhroat. $I_{1}$ is a most beautiful variety and a very strong and rank grower under nearly all eonditions.

No. 5. Mrs. Frank Pendleton One of the most beautiful Gladioli, combilling the beauty are round and immense in size and of great substance, the eolor being a soft rosy pink on white ground
while the throal is a rich blood-red. A ta!l, strong grower.

No. 6. Prince of Wales if you want one of the very earliest Gladioli, you musi plant Prince spikes, producing immense sized foovers of the most delicate salmononink of roseate tinge; lower petals
ereamy writh erimson peneiling. The large waxy flowers are admired by all, and being so extremely early it should be in every Hower garden.

No. 7. Flora A very large variety and if given rich soil and good eare will produce wonderful A very late valely and is yiven rich sol and many buds reaching to the very tip of the stalk. Tle color is clear canary-yellow with a shading on
the lower petals of a deeper yellow and a touch of dark red in the throat. It is one of the best yellows and in favorite wherever seen growing.

No. 8. Jewell Here is a variety that aturacts a great deal of attention everywhere, It is a forist's grow medium height, very sirong and stocky and produre large, wide open, bell-shaped powers of the most beautiful rich deep rose color, with a golden yellow bloteh and throat beautifully tinled. Wc know of no other variety of Gladiolus anywhere near like il and all who grow it will have some1hing very

No. 9. Anna Eberius This is a splendid variety, making a tall, strong spike. It is a rapid large and well formed, of the most rich, dark maroon-red color with purphish markings. It is a very

No. 10. Le Marechal Foch A mosi beautiful variety of a lovely rose-pink. Flower spike is one of the finest of recent introduction. We believe it is the softest and has the most eharming tone

No. 11. Conspicuous The vety unusual color combination makes this varicty highly conlavender with erimson and vellow throat beautifully tinted, giving it the alpearance of a pansy, in fact lavender with erimson and yellow throat beautifully tinted, giving
many eall it the Pansy-Gladiolus. It is very striking and beauliful.

No. 12. Mrs. Watt Here is a variety admised by all flower lovers. It is a glowing Ameriezn most fovely sort. $l_{1}$ is very distinet, of medium groweth, producing a good spike filled to the very tip
with fowers and buds. It is a variety that is sure to please.

\section{Why "Glads" Should Be Planted}

There is no flower that has so lately increased in popularity as the Gladiolus. During the past few years wonderful improvements have been made in the development of new and beautiful varieties. Those which we show arc truly magnificent in their size and beauty. Our aim is not to offer the largest list but to offer a selection of the hnest varieties for home culture.

The Gladiolus is one of the most decorative plants in the garden and as a cut flower lends itself readily to any arrangement. If the spikes are cut wher the lowest flower is in bloom, the others will open in succession and remain fresh for a week or ten days

No fower has gatned more rapidly in public favor than the Gladiolus this could not well be otherwise, for in addition to the great intrinsic merit of the flower, it is hardy and blooms the first season.

\section{When to Plant}

Gladioli should be planted in the Spring and can be successfully plinted ny time after trees are out in leat until the last of June.

\section{Care Required}

The culture of Gladioit is very simple and satisfactory results can be obtained even under the most orcinary conditions. All that is required is fairly good soil and enough attention to keep the weeds down, and in very dry weather, watering during the bloomitug period is of benefit; one good
soaking a week in tlic evening is better than a dozen light sprinkles, as winter must get down to roots to be of benent.

\section{How to Plant}

If best spikes for cutting are wanted, plant the bulbs 4 inches deep. A good vay is to furrow out a row that is about four inches deep and four inches way is to furrow out a row that is abolt four inces deep and four ince wide at the boton and then plant the buibs staggering or aigzage Cover to about one inch and as they grow up thrugh. hoe a jitle more earth over them of the can cond If the soil is not very rich it is advisable to put a liberal level of the ground. If the soil is thoroughly mined with the soil at planting

Some people plant Gladioli among their perennials or they make a won. derful showing when planted alone.

In the Fall they should be dug and planted again the following year. As a usual thing they are dug in November allowing them to lay outdoors ivhere they will not freeze or be exposed to the sun for two or three days unthe will not freeze and yet will be avay from heat 


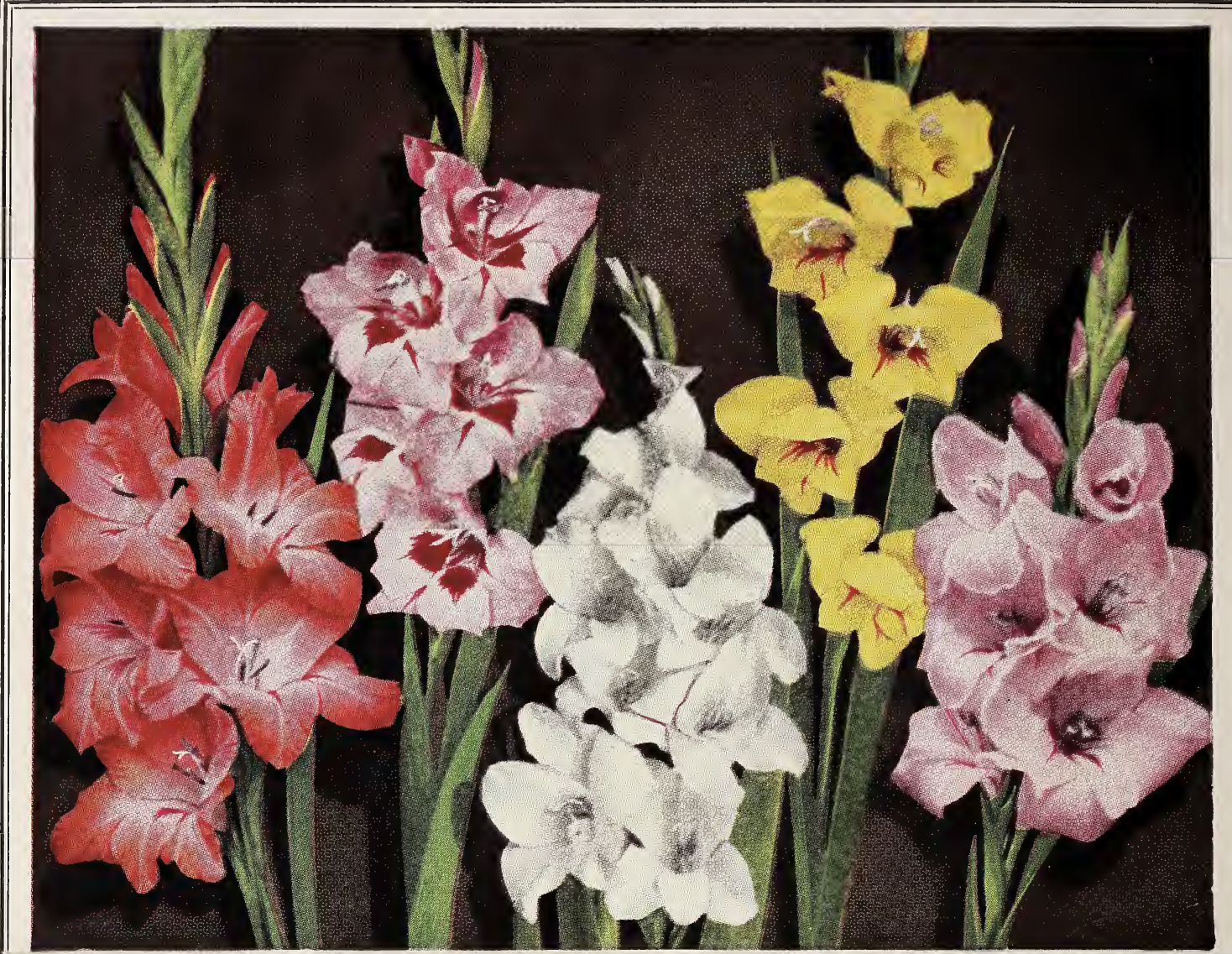

Our Gladiolus assortment will be carefully packed and should give an abundance of bloom the first season planted

This collection must in no way be classed with the ordinary Gladiolus. The bulbs which we offer in this excellent group are specially selected bulbs of good size, and beautiful varieties, giving the purchaser an array of color throughout the Summer months.

In order to give the benefit of this special bargain price no change may be made from this assortment, which contains one each of the 12 named varieties.

\section{Bargain Price for the Group of Twelve $\$ 2.50$ Only}

Two Collections-24 Gladioli-Two of a Variety, $\$ 4.50$

\section{QUANTITY PRICES}

50 Gladioli - - - - $\$ 8.00$

100 Gladioli - - - - 15.00

500 Gladioli - - - - 70.00

1000 Gladioli - - - - 125.00

Not less than ten of any kind 